\title{
Src Plays a Key Role in ADAM28 Expression in v-src-Transformed Epithelial Cells and Human Carcinoma Cells
}

\author{
Hitoshi Abe, ${ }^{* \dagger}$ Satsuki Mochizuki, ${ }^{*}$ Kentaro Ohara, ${ }^{*}$ Mari Ueno, ${ }^{*}$ Hiroki Ochiai, ${ }^{\ddagger}$ Yuko Kitagawa,${ }^{\ddagger}$ Okio Hino, ${ }^{\dagger}$ Hiroshi Sato, ${ }^{\S}$ and \\ Yasunori Okada*
}

From the Departments of Pathology* and Surgery, ${ }^{\ddagger}$ School of Medicine, Keio University, Tokyo; the Department of Pathology and Oncology, ${ }^{\dagger}$ School of Medicine, Juntendo University, Tokyo; and the Department of Molecular Virology and Oncology, ${ }^{\S}$ Cancer Research Institute, Kanazawa University,

Kanazawa, Japan

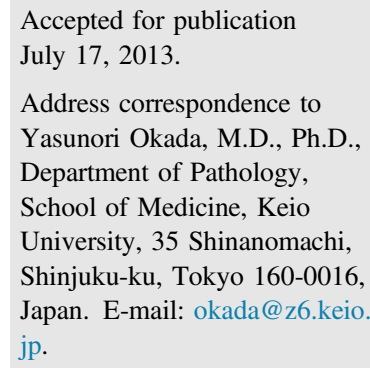

ADAMs (a disintegrin and metalloproteinases) are multifunctional proteins, showing various biological activities, such as ectodomain shedding of transmembrane proteins, cell adhesion and migration, growth factor metabolism, and cell signaling. ${ }^{1-3}$ The human ADAM family is composed of 13 proteolytic ADAMs that exhibit proteinase activity and eight nonproteolytic ADAMs. ${ }^{1,3}$ Proteolytic ADAMs share the metalloproteinase domain with that of matrix metalloproteinases (MMPs), and a typical proteolytic ADAM protein comprises propeptide, metalloproteinase, disintegrin-like, cysteine-rich, epidermal growth factor-like, transmembrane, and cytoplasmic domains. ${ }^{4-8}$ Previous studies have demonstrated that $A D A M 8$, ADAM9, ADAM10, ADAM12, ADAM15, ADAM17, ADAM19, and $A D A M 28$ are overexpressed in various human cancers and are associated with tumor growth and progression. ${ }^{7,9}$ Among them, we focused on ADAM28 because of its predominant expression by carcinoma cells in human carcinomas. ${ }^{10}$ Our previous studies have demonstrated that $A D A M 28$ is abundantly expressed in human non-small cell lung and breast carcinomas. ${ }^{11,12}$ In situ hybridization and immunohistochemistry

\footnotetext{
Supported by a Grant-in-Aid for Scientific Research (C) from the Japan Society for the Promotion of Science (JSPS) and an External Collaborative Research Grant of the Cancer Research Institute, Kanazawa University (S.M.), a Grant-in-Aid for Scientific Research (A) from JSPS and Third Term 10-year Strategy for Cancer Control from the Ministry of Health and Welfare (Y.O.), and a Grant-in-Aid for the Global Center of Excellence program from JSPS (Keio University).

H.A. and S.M. contributed equally to this work.
} 
(IHC) have indicated that ADAM28 is expressed predominantly by carcinoma cells in these carcinoma tissues and that the mRNA expression levels of $A D A M 28$ directly correlate with the cellular proliferation of breast carcinomas ${ }^{12}$ and with both carcinoma cell proliferation and metastasis in the non-small cell lung carcinomas. ${ }^{11}$ Our parallel study has shown that serum levels of ADAM28 in the patients with non-small cell lung carcinoma significantly increase with tumor staging, lymph node metastasis, and carcinoma recurrence. ${ }^{13}$ We have also demonstrated that ADAM28 contributes to carcinoma cell proliferation and metastasis, through enhanced bioavailability of insulin-like growth factor-I (IGF-I), by selective digestion of IGF-binding protein-3 (IGFBP-3) of the IGF-I/IGFBP-3 complex, ${ }^{12,14}$ and through enhanced carcinoma cell survival, by digestion of von Willebrand factor (VWF) and then escape from VWF-induced apoptosis within the bloodstream ${ }^{15}$; in addition, ADAM28 contributes to angiogenesis by digestion of connective tissue growth factor (CTGF) in breast carcinomas. ${ }^{16}$ Other groups have described the possibility of ADAM28 as a biomarker for asbestos-related lung carcinomas ${ }^{17}$ and bladder transitional cell carcinomas. ${ }^{18}$ These data implicated ADAM28 in cell proliferation and metastasis in the particular human cancers. Concerning the expression of ADAM28, exposure of human monocyte-like THP-1 cells to phorbol myristate acetate or low-density lipoprotein is reported to up-regulate the gene expression. ${ }^{19,20}$ However, no information is available for the inducers of ADAM28 gene expression in malignant neoplastic epithelial cells.

In the current study, we aimed to examine the expression mechanisms by which $A D A M 28$ is induced and/or upregulated in oncogene-transformed cells and human carcinoma cell lines. Our data have indicated that transformation of Madin-Darby canine kidney (MDCK) epithelial cells by v-src, but not latent membrane protein 1 (LMP1), ErbB2, Ha-Ras, or c-Fos, induces ADAM28 expression through activation of mitogen-activated protein kinase kinase (MEK)/extracellular signal-regulated kinase (ERK) and phosphatidylinositol 3-kinase (PI3K)/Akt/mammalian target of rapamycin (mTOR) pathways. Our study also demonstrates that activation of Src and its downstream signaling pathways are essential to overexpression of ADAM28 in human carcinoma cells.

\section{Materials and Methods}

\section{Cell Lines and Cultures}

MDCK cells transformed by v-src, $L M P-1$, or ErbB2 were developed and characterized previously. ${ }^{21-23}$ For preparation of the transformants stably expressing Ha-Ras or c-Fos, MDCK cells were transfected with expression plasmids that contained a selectable $n e o^{\mathrm{r}}$ gene (neomycin phosphotransferase gene of Escherichia coli) for Ha-Ras gene, with a point mutation within the codon $12(\mathrm{Gly} \rightarrow \mathrm{Val})^{24}$ or c-Fos gene. ${ }^{25}$ Transfected cells were cultured in the presence of G418, and the resistant cells were cloned. These cells were cultured in Dulbecco's modified Eagle's medium supplemented with $10 \%$ fetal bovine serum, penicillin, and streptomycin (Sigma-Aldrich, St. Louis, MO) and used for experiments. Because v-src transformants lacked cell-to-cell contacts, MDCK cells maintained in monolayer and suspension cultures were used as for controls. Human cell lines of lung carcinoma (PC-9 and Calu-3), breast carcinoma (MDA-MB231 and MCF-7), ovarian carcinoma (RMUGL and TOV21G), renal cell carcinoma (Caki-2 and 769P), colon carcinoma (HCT15 and LOVO), and hepatocellular carcinoma (HepG2) were cultured in Dulbecco's modified Eagle's medium for MDA-MB231 and MCF-7 cells or in RPMI 1640 medium for other cell lines, both of which were supplemented with $10 \%$ fetal bovine serum, penicillin, and streptomycin.

\section{RT-PCR and Immunoblotting}

Total RNA was isolated from canine and human cell lines by Isogen (Nippon Gene Co Ltd, Tokyo, Japan). The reverse transcription reaction was performed at $42^{\circ} \mathrm{C}$ for 60 minutes, followed by heating at $99^{\circ} \mathrm{C}$ for 5 minutes for inactivation of the enzyme. ${ }^{11,12}$ Information about the sequences for canine ADAM28, ADAM9, ADAM10, ADAM12, $A D A M 15, A D A M 17$, and housekeeping gene $\beta$-actin was obtained from UniProt (http://www.uniprot.org, last accessed September 4, 2013) and Gene Card (http://www. genecards.org, last accessed September 4, 2013), and the cDNAs were amplified by PCR with the primers specific to each gene: forward primer 5'-GGATAACATATTGTGGGCACATGG-3' $3^{\prime}$ and reverse primer $5^{\prime}$-TGGAAAAATTTTCCAGGGTGGAGC-3' for ADAM28; forward primer 5'GTAATAAATTGGTGGATCCTGGGG- $3^{\prime}$ and reverse primer 5'-AACACGTTAATCCCGCCTGCGT- $3^{\prime}$ for ADAM9; forward primer $5^{\prime}$-ATTTACCAGACCACAGACTTCTCC$3^{\prime}$ and reverse primer 5'-AGTAATGTGAGAGACTTTGGGAGG-3' for ADAM10; forward primer 5'-TTCCCCATGGTGTTCAGCAGCT- $3^{\prime}$ and reverse primer $5^{\prime}$-GATGCCGTTGTAGCAGTAGCCA-3' for ADAM12; forward primer $5^{\prime}$-ACATTCTTCCGGCCCCTGAAT- $3^{\prime}$ and reverse primer 5'-CGGCTGCAGTTGCTGAAGTTCA-3' for ADAM15; forward primer $5^{\prime}$-CCTAGCGGAATGTGCCCCAAAT- $3^{\prime}$ and reverse primer $5^{\prime}$-GGCACTCACTGCTGTTACCTGT- $3^{\prime}$ for ADAM17; and forward primer 5'-GGATAACATATTGTGGGCACATGG- $3^{\prime}$ and reverse primer $5^{\prime}$-TGGAAAAATTTTCCAGGGTGGAGC- $3^{\prime}$ for $\beta$-actin. For human cell lines, primers specific to human ADAM28s and ADAM28m were prepared as described previously. ${ }^{11} \mathrm{PCR}$ amplification by Takara ExTaq (Takara Bio Inc., Shiga, Japan) was performed on a thermal cycler after an initial denaturation at $94^{\circ} \mathrm{C}$ for 3 minutes by running 25 cycles for canine $A D A M s$ and $\beta$-actin, 30 cycles for human $A D A M 28 s$ and $A D A M 28 m$, and 25 cycles for human $\beta$-actin under the following conditions: denaturation for 1 minute at $94^{\circ} \mathrm{C}$, annealing for 1 minute at $56^{\circ} \mathrm{C}$ (human $A D A M 28 s$ and $A D A M 28 m$ ), $67^{\circ} \mathrm{C}$ (human $\beta$-actin), or $60^{\circ} \mathrm{C}$ (canine ADAMs and $\beta$-actin), and extension for 1 minute at 
$72^{\circ} \mathrm{C}$, followed by a final extension for $>3$ minutes. The expected sizes of the amplified cDNA fragments for canine ADAM28, ADAM9, ADAM10, ADAM12, ADAM15, ADAM17, and $\beta$-actin were $287,256,373,412,441,408$, and $614 \mathrm{bp}$, and those for human ADAM28s, ADAM28m, and $\beta$-actin were 544, 871 , and $661 \mathrm{bp}$, respectively. The products were electrophoresed on $2 \%$ agarose gels and stained with ethidium bromide.

For immunoblotting of ADAM28, homogenate supernatants of MDCK cells, oncogene-transformed MDCK cells, and human carcinoma cells (10 $\mu \mathrm{g}$ per lane) were subjected to SDS-PAGE under the reducing conditions, and resolved proteins on gels were transferred onto polyvinylidene difluoride membranes. The membranes were blotted with 1 $\mu \mathrm{g} / \mathrm{mL}$ mouse anti-ADAM28 monoclonal antibody specific to the metalloproteinase domain of human ADAM28 $(297-2 \mathrm{~F} 3)^{11,12}$ or $0.2 \mu \mathrm{g} / \mathrm{mL}$ anti- $\beta$-actin antibody (SigmaAldrich), and then the immunoreactive bands were detected with electrochemiluminescence Western blot reagents (GE Healthcare Bio-Sciences, Uppsala, Sweden). Crossreactivity of anti-ADAM28 antibody (297-2F3) to canine ADAM28, the metalloproteinase domain of which has 96\% homology to human ADAM28 (National Center for Biotechnology Information, http://www.ncbi.nlm.nih.gov/ protein/XP_850956.2, last accessed September 4, 2013), was shown by immunoblotting (data not shown). Activation of Src and Ras was determined by immunoblotting for phospho-Src with $0.1 \mu \mathrm{g} / \mathrm{mL}$ anti-phospho-Src antibody and by immunoblotting for active Ras using a pull-down assay for the GTP-bound active form of Ras proteins (Cytoskeleton, Inc., Denver, CO). Overexpression of LMP1, ErbB2, and c-Fos was confirmed by immunoblotting with 1 $\mu \mathrm{g} / \mathrm{mL}$ antibodies against LMP1 (DakoCytomation, Carpinteria, CA), $0.2 \mu \mathrm{g} / \mathrm{mL}$ ErbB2, or $0.2 \mu \mathrm{g} / \mathrm{mL}$ c-Fos, respectively. To study intracellular signaling pathways for ADAM28 expression, transformed MDCK cells were incubated with various inhibitors, including $1 \mu \mathrm{mol} / \mathrm{L} \mathrm{Src}$ inhibitor (PP2), $1 \mu \mathrm{mol} / \mathrm{L}$ control inactive peptide for PP2 (PP3), $5 \mu \mathrm{mol} / \mathrm{L}$ radicicol, $50 \mu \mathrm{mol} / \mathrm{L}$ PD98050, $5 \mu \mathrm{mol} / \mathrm{L}$ U0126, $5 \mu \mathrm{mol} / \mathrm{L}$ U0124, $20 \mu \mathrm{mol} / \mathrm{L} \mathrm{LY} 294002,10 \mu \mathrm{mol} / \mathrm{L}$ rapamycin, $10 \mu \mathrm{mol} / \mathrm{L}$ c-Jun $\mathrm{N}$-terminal kinase (JNK) inhibitor, $10 \mu \mathrm{mol} / \mathrm{L}$ P38 inhibitor, $2.5 \mu \mathrm{mol} / \mathrm{L}$ FTI-277, and $2.5 \mu \mathrm{mol} / \mathrm{L}$ FPT inhibitor 1 under serum-free culturing conditions for 48 hours; then, cell lysates (10 $\mu \mathrm{g}$ per lane) were subjected to immunoblotting with $0.1 \mu \mathrm{g} / \mathrm{mL}$ antibodies against phospho-Src, Src, phospho-ERK1/2, ERK1/ 2, phospho-Akt, or Akt. For human carcinoma cell lines, immunoblotting for secreted short form of ADAM28 (ADAM28s) and membrane-anchored ADAM28 (ADAM28m) was performed by using $1 \mu \mathrm{g} / \mathrm{mL}$ antiADAM28 monoclonal antibody $(297-2 \mathrm{~F} 3)^{11,12}$ and antiADAM28 antibody for the cytoplasmic domain (Abcam, Cambridge, UK). ADAM28-expressing human carcinoma cell lines were treated with $1 \mu \mathrm{mol} / \mathrm{L}$ PP2 and $1 \mu \mathrm{mol} / \mathrm{L} \mathrm{PP} 3$ for 48 hours, and ADAM28s expression and phosphorylation of Src were determined by immunoblotting. Cell signaling pathways were also examined by immunoblotting of ADAM28s, phospho-Src, phospho-ERK1/2, and phosphoAkt with the cell lysates of PC-9 cells treated with $50 \mu \mathrm{mol} / \mathrm{L}$ PD98050, $20 \mu \mathrm{mol} / \mathrm{L}$ LY294002, or combined inhibitors for 48 hours. The levels of ADAM28 expression (ADAM28/ $\beta$-actin) and phosphorylation of Src, ERK1/2, Akt, and mTOR were analyzed by densitometric quantification of the immunoblots from three separate experiments. All of the inhibitors and antibodies, unless otherwise stated, were purchased from Calbiochem (San Diego, CA) and Cell Signaling Co (Beverly, MA), respectively.

\section{Immunocytochemistry and Immunoelectron Microscopy}

MDCK cells and those transformed by $L M P-1, \operatorname{ErbB} 2$, Ha-Ras, or c-Fos were cultured on the Lab-Tek chamber slide (Nalge Nunc International, Rochester, NY) and fixed in $4 \%$ paraformaldehyde (PFA) for 15 minutes. Because $\mathrm{v}$-src-transformed cells were cultured under suspension, they were subjected to cytospin onto slide glass (Thermo Electron Corporation, Pittsburgh, PA) and then fixed with $4 \%$ PFA. All these cells were treated with $0.05 \%$ Tween20 in PBS for 5 minutes and then reacted with $10 \mu \mathrm{g} / \mathrm{mL}$ anti-ADAM28 antibody (297-2F7), followed by incubation with goat antibody against mouse or rabbit IgG conjugated with horseradish peroxidase-labeled dextran polymer (no dilution; EnVision+ Peroxidase; DakoCytomation, Carpinteria, CA). For immunoelectron microscopy, v-srctransformed cells were fixed with $2 \% \mathrm{PFA}$ in $0.1 \mathrm{~mol} / \mathrm{L}$ phosphate buffer and then embedded in LR White resin (London Resin, Berkshire, UK). Ultrathin sections mounted on Formvar carbon-coated nickel grids were incubated with $10 \mu \mathrm{g} / \mathrm{mL}$ anti-ADAM28 antibody (297-2F7) or antiphospho-Src (Tyr416) antibody (Cell Signaling Co) after blocking a non-specific reaction with $1 \%$ bovine serum albumin in PBS, and then reacted with 15 -nm gold-labeled goat anti-mouse IgG or 15-nm gold-labeled goat anti-rabbit IgG (GE Healthcare UK Ltd, Buckinghamshire, UK). As for control, sections were treated with nonimmune IgG by replacing the first antibodies. After the immunoreactions, sections on the grid were reacted with $2 \%$ osmium tetroxide and stained with uranyl acetate and lead citrate.

\section{In Vivo Growth of MDCK Cells and Oncogene Transformants and Effects of Anti-ADAM28 Antibody on Growth of v-src Transformants in Immunodeficient Mice}

Cell suspensions $\left(5 \times 10^{6}\right.$ cells in $0.1 \mathrm{~mL}$ HBSS $)$ of MDCK cells and those transformed by v-src, LMP1, ErbB2, HaRas, or c-Fos were injected s.c. at both sides of the back of male BALB/c-nu-nu mice (Charles River, Yokohama, Japan), and tumor growth was monitored for 15 days ( $n=6$ per each group). For the experiment of antibody treatment, mice that received inoculation of $\mathrm{v}$-src-transformed cells 
were randomly divided into two groups $(n=6$ per each group); then, they were treated with $2 \mathrm{mg} / \mathrm{kg}$ per day of anti-ADAM28 antibody $(297-2 \mathrm{~F} 3 ;)^{12,15}$ or $2 \mathrm{mg} / \mathrm{kg}$ per day of nonimmune mouse IgG. The antibody solution or nonimmune $\operatorname{IgG}(100 \mu \mathrm{L}$ in PBS $)$ was injected into the s.c. tissues near the xenografts on days $1,3,5$, and 7 after the inoculation by modification of our methods for siRNA treatment. ${ }^{12}$ The three dimensions, height, length, and width, of each tumor were measured at the indicated times, and volumes were calculated according to the following formula ${ }^{12}$ :

$$
\begin{aligned}
\text { Volume }= & {\left[\pi h\left(h^{2}+3 a^{2}\right)\right] / 6, \text { where } \mathrm{h}=\text { height; } } \\
& \mathrm{a}=(\text { length }+ \text { width }) / 4 .
\end{aligned}
$$

The growth curve of MDCK cells and transformants by v-src, $L M P 1$, or ErbB2 after being inoculated in nonobese diabetic (NOD)/severe combined immunodeficiency (SCID) mice (Charles River) was also monitored for 15 days $(n=6$ per each group). Housing and maintenance of mice and all procedures were performed according to the Guidelines for the Care and Use of Laboratory Animals of the School of Medicine, Keio University (Tokyo, Japan).

\section{Histological Characteristics of Xenografts in Immunodeficient Mice and IHC of ADAM28 and Phospho-Src in the Tumors}

Mice received inoculation of MDCK cells, oncogene transformants were sacrificed by cervical dislocation at 15 days after cell injection, and the tumor tissues were removed, fixed in 4\% PFA, and embedded in paraffin. Sections $(4 \mu \mathrm{m}$ thick) were prepared and stained with H\&E. For IHC analysis, paraffin sections of tumor tissues removed from the NOD/SCID mice with injections of MDCK cells transformed by v-src, $L M P 1$, or ErbB2 were subjected to immunostaining. The immunostaining was performed with $10 \mu \mathrm{g} / \mathrm{mL}$ anti-ADAM28 antibody (2972F3), 1:50 rabbit anti-phospho-Src (Tyr416) antibody (Cell Signaling Co), anti-LMP1 antibody (DakoCytomation), anti-ErbB2 antibody (Cell Signaling Co), or nonimmune mouse or rabbit IgG after antigen retrieval by autoclaving at $120^{\circ} \mathrm{C}$ for 10 minutes and blocking endogenous peroxidase and non-specific reaction. ${ }^{11,12}$ After reaction with secondary antibodies with horseradish peroxidase-labeled dextran polymer (no dilution; EnVision+ Peroxidase; DakoCytomation), color was developed with 3,3'-diaminobenzidine tetrahydrochloride and the sections were counterstained with hematoxylin.

\section{Clinical Samples, Histological Characteristics, and IHC}

Paraffin sections ( $4 \mu \mathrm{m}$ thick) were made from the paraffinembedded tumor tissues from patients with primary breast carcinoma $(n=6)$, non-small cell lung carcinoma $(n=6)$, colon adenocarcinoma $(n=8)$, or tubular adenoma of the colon $(n=8)$, who underwent surgery at Keio University

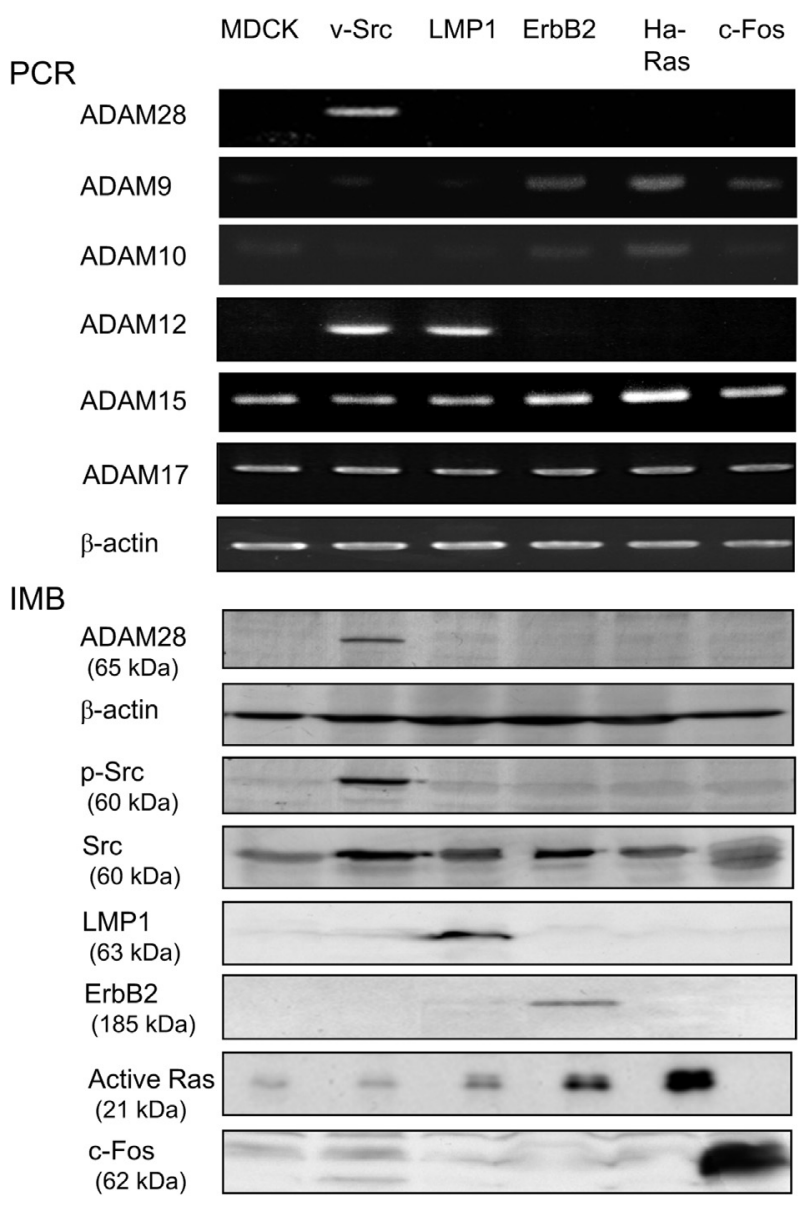

Figure 1 Expression of ADAM28 and phosphorylation of Src in MDCK epithelial cells and those transformed by v-src, LMP1, ErbB2, Ha-Ras, or c-Fos. The mRNA and protein expression of ADAM28 was examined by RT-PCR and immunoblotting (IMB), respectively, and phosphorylation of Src (p-Src) was determined by immunoblotting with anti-phospho-Src antibody. mRNA expression of ADAM9, ADAM10, ADAM12, ADAM15, and ADAM17 was also examined by RT-PCR in these cells. Overexpression of LMP1, ErbB2, and c-Fos and activation of Ras were verified by immunoblotting, as described in Materials and Methods. $\beta$-Actin was used as a loading control.

Hospital (Tokyo). Nonneoplastic colon tissues $(n=8)$ were selected from sites remote from colon adenocarcinoma. None of the patients had received chemotherapy or radiation therapy before surgery. The sections were dewaxed and stained with H\&E. For IHC, they were subjected to immunostaining with $10 \mu \mathrm{g} / \mathrm{mL}$ mouse monoclonal anti-ADAM28 antibody (297-2F3), rabbit anti-phospho-Src (Tyr416) antibody (1:50 dilution; Cell Signaling Co), or nonimmune mouse or rabbit $\mathrm{IgG}$, as previously described, and then counterstained with hematoxylin. Informed consent for experimental use of the surgical samples was obtained from the patients according to the hospital ethical guidelines.

\section{Statistical Analysis}

Results between the two independent groups were determined by the $U$-test. Comparisons among more than three groups were determined by the Kruskal-Wallis test. Statistical analyses were performed using StatView statistical 


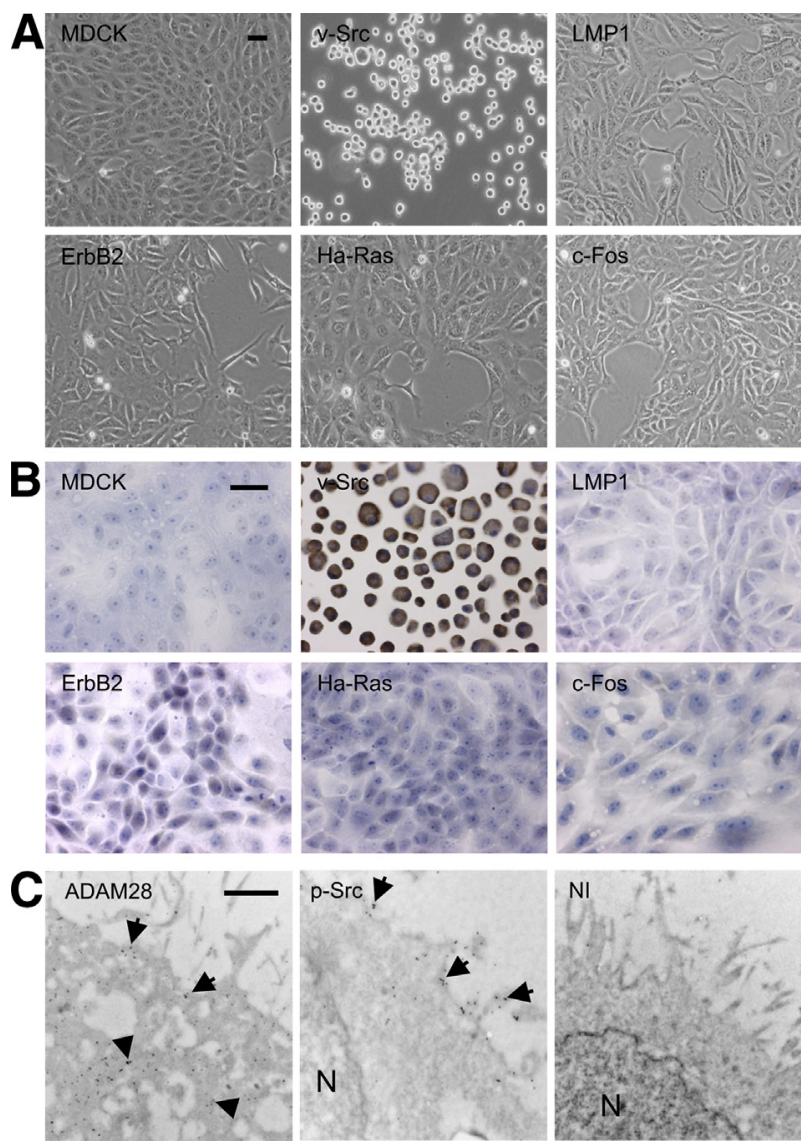

Figure 2 Morphological changes in MDCK epithelial cells transformed by oncogenes and immunolocalization of ADAM28 and phospho-SrC in v-src-transformed MDCK cells. A: Phase-contrast microscopic observation of MDCK cells and oncogene transformants. B: Immunocytochemistry of ADAM28 in MDCK and oncogene-transformed MDCK cells. C: Immunoelectron microscopy of ADAM28 and phospho-Src ( $\mathrm{p}-\mathrm{Src})$. Arrows and arrowheads indicate immunoreactive gold particles on cell membrane and in cytoplasm, respectively. Uranyl acetate and lead citrate staining was used. $N$, nucleus; NI, nonimmune IgG. Scale bars: $50 \mu \mathrm{m}(\mathbf{A}) ; 100 \mu \mathrm{m}($ B) $; 1 \mu \mathrm{m}$ (C).

software version 5 (SAS Institute Inc., Cary, NC) on a personal computer. $P<0.05$ was considered significant.

\section{Results}

\section{Selective Expression of ADAM28 in MDCK Epithelial Cells Transformed by v-src}

When the mRNA and protein expression of ADAM28 was examined by RT-PCR and immunoblotting, MDCK cells maintained in monolayer or suspension culture showed no or negligible expression of ADAM28 (Figure 1 and data not shown for MDCK cells cultured in suspension). On the other hand, v-src-transformed MDCK cells exhibited ADAM28 expression, whereas MDCK cells transformed with $L M P 1$, ErbB2, Ha-Ras, or c-Fos did not show detectable levels of ADAM28 expression (Figure 1). The expression of ADAM9 was observed in ErbB2-, Ha-Ras-, or c-Fos-transformed cells, and ADAM10 was expressed in ErbB2- or Ha-Ras transformants (Figure 1). ADAM12 was induced in v-src- or
LMP-1-transformed cells, whereas the expression of $A D A M 15$ and $A D A M 17$ appeared to be constitutively positive in the MDCK cells and oncogene transformants. Immunoblotting analysis demonstrated phosphorylation of Src (phospho-Src) only in v-src-transformed MDCK cells, although the Src protein was present in control and other oncogenetransformed MDCK cells (Figure 1). Overexpression of LMP1, ErbB2, and c-Fos and activation of Ras were also verified by immunoblotting in the corresponding transformants (Figure 1). These data demonstrate that activation of Src is involved in ADAM28 induction in $\mathrm{v}-\mathrm{src}$-transformed MDCK cells and suggest that ADAM9, ADAM10, and ADAM12 are also inducible in the transformants by other oncogenes.

Control MDCK cells exhibited the characteristic cobblestone morphological characteristics (Figure 2A). In contrast,
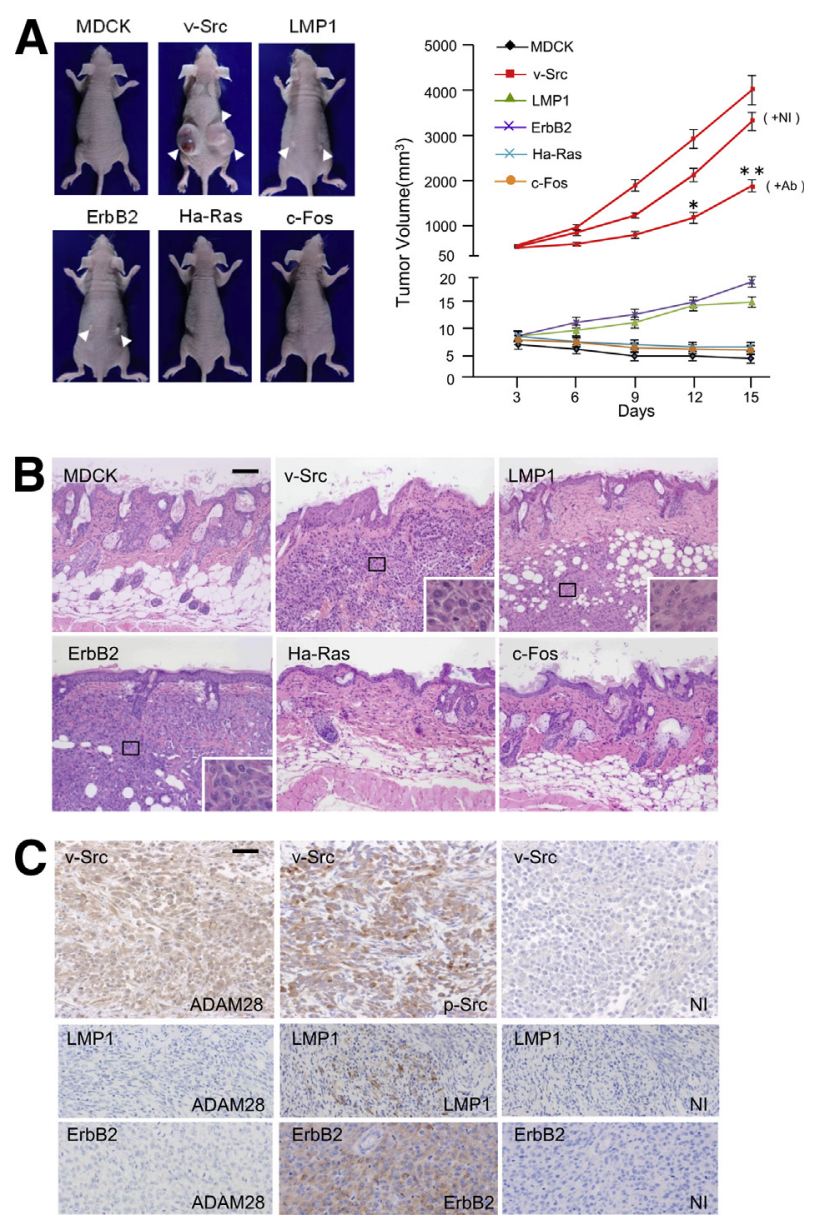

Figure 3 Tumor growth of MDCK epithelial cells and oncogenetransformed MDCK cells and IHC of the oncogene transformants in immunodeficient mice. A: The cells were s.c. injected into athymic nude mice, and tumor growth was monitored according to the methods described in Materials and Methods. Arrowheads indicate tumors. Effect of local injections of anti-ADAM28 antibody $(+\mathrm{Ab})$ or nonimmune mouse IgG $(+\mathrm{NI})$ on the tumor growth of v-src transformants was also determined. ${ }^{*} P<0.05,{ }^{* *} P<$ 0.01 (anti-ADAM28 antibody versus nonimmune IgG). B: Microscopic observation of xenografts removed at 15 days after s.c. injection of MDCK cells and oncogene transformants. Insets: Higher-power view of the squared area. C: IHC of ADAM28, phospho-Src (p-Src), LMP1, and ErbB2 in tumor tissues grown in NOD/SCID mice after injection of MDCK transformants by v-srC, LMP1, or ErbB2. NI, nonimmune IgG. Scale bars: $100 \mu \mathrm{m}$ (B); $50 \mu \mathrm{m}$ (C). 

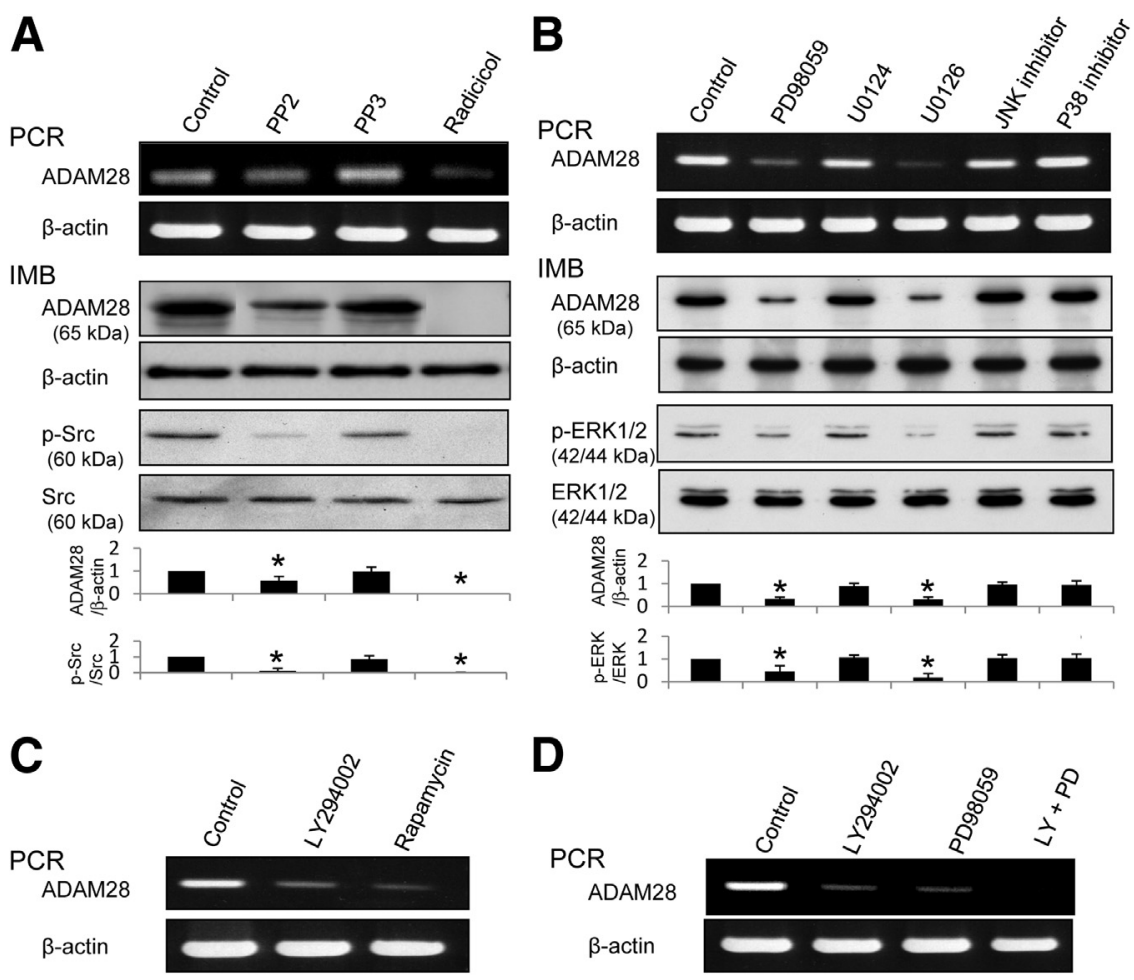

IMB

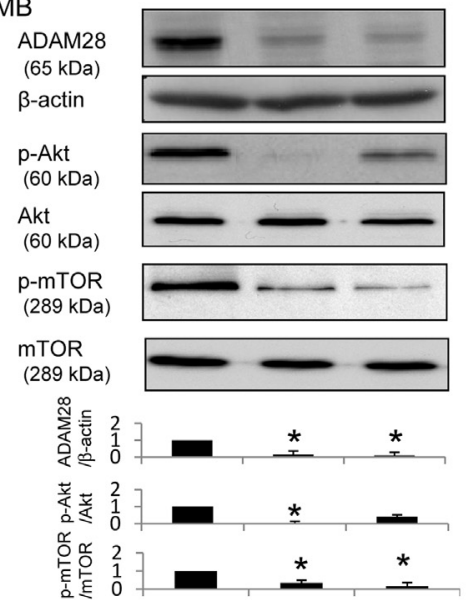

D

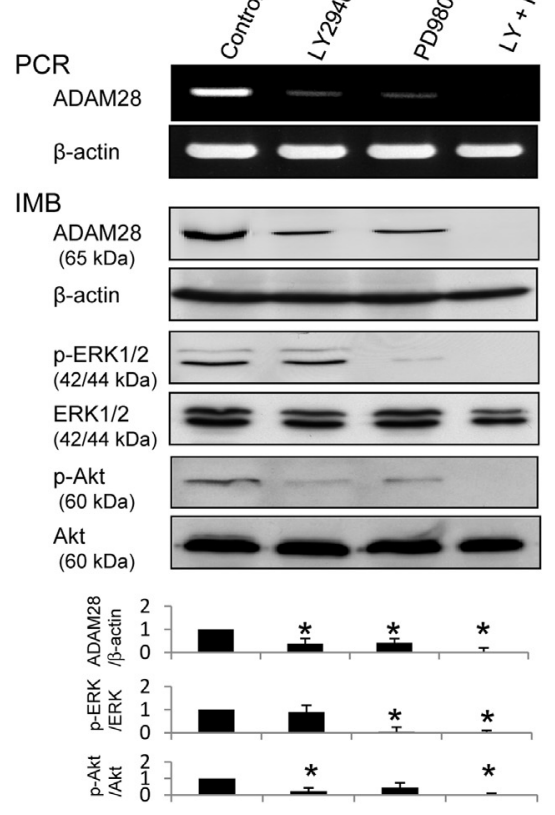

Figure 4 Involvement of MEK/ERK and PI3K/ Akt/mTOR pathways in induction of ADAM28 in v-src transformants. A: The expression of ADAM28 mRNA and protein in $v$-src transformants by treatment with PP2 and v-Src inhibitor (radicicol). $\beta$-Actin was used as a loading control. B: Effects of pharmacological inhibitors to the molecules of the MAPK family on ADAM28 expression and phosphorylation of ERK1/2 (p-ERK1/2). v-src Transformants were treated with MEK inhibitors (PD98059 and U0126), JNK inhibitor, or p38 inhibitor, and then ADAM28 expression and ERK1/2 phosphorylation was examined. C: Effects of PI3K inhibitor (LY294002) and mTOR inhibitor (rapamycin) on ADAM28 expression and phosphorylation of Akt ( $p-A k t)$ in v-src transformants. D: Additive effect of MEK inhibitor (PD98059) and PI3K inhibitor (LY294002) on the expression of ADAM28, p-ERK1/2, and p-Akt. Relative expression levels of ADAM28 and signaling molecules were quantitatively evaluated by densitometric analysis of the triplicate immunoblots. ${ }^{*} P<0.05$. IMB, immunoblotting; PCR, RT-PCR. v-src transformants showed round morphological characteristics without cell-to-cell contacts, and MDCK cells transformed with $L M P 1$ or ErbB2 had spindle-shaped morphological characteristics. MDCK transformants by HaRas or c-Fos retained the cobblestone morphological characteristics, although they appeared to be composed of more spindle-shaped cells than control MDCK cells. Immunocytochemistry demonstrated that only $\mathrm{v}$-s $r c$-transformed MDCK cells produce ADAM28, which was localized mainly around the cell membrane, although some cells showed cytoplasmic staining as well (Figure 2B). Immunoelectron microscopy indicated that ADAM28 is localized on cell membrane and in cytoplasm, whereas phospho-Src protein was detected mainly on cell membrane (Figure 2C). Negligible signals were observed with nonimmune IgG (Figure 2C and data not shown for immunocytochemistry).
Implantation of Oncogene-Transformed MDCK Cells in Immunodeficient Mice

MDCK cells and those transformed with v-src, LMP1, ErbB2, Ha-Ras, or c-Fos were s.c. injected into athymic nude mice $(5 \times$ $10^{6}$ cells per mouse), and tumor growth was monitored. As shown in Figure 3A, v-src-transformed MDCK cells formed prominent tumors at 15 days after injection, but only small tumor nodules were detected with LMP1- or ErbB2-transformed cells and other transformants showed negligible tumors. When neutralizing anti-ADAM28 antibody was injected four times around the tumors of $\mathrm{v}-\mathrm{src}$ transformants grown in the s.c. tissue, tumor growth was significantly suppressed compared with control tumors with injections of nonimmune IgG (Figure 3A). Microscopically, tumor cell growth was observed in the s.c. tissues from mice with implantation of $\mathrm{v}-s r c-, L M P 1-$, or 


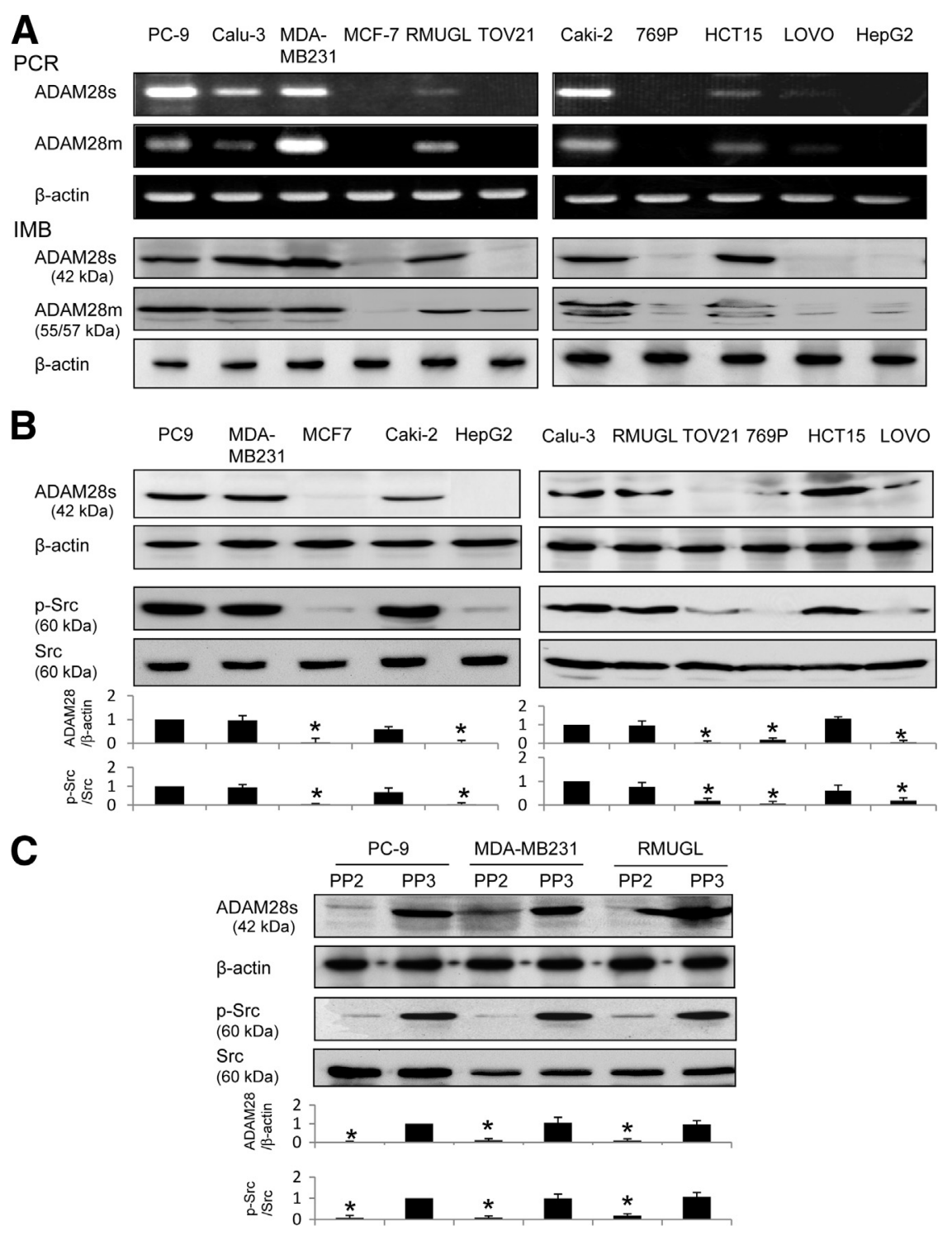

Figure 5 Correlation between ADAM28 expression and phosphorylation of c-Src and downregulation of ADAM28 expression by Src-kinase inhibitor in human carcinoma cell lines. A: The expression of ADAM28s and ADAM28m in human cell lines of the lung (PC-9 and Calu-3), breast (MDA-MB231 and MCF-7), ovarian (RMUGL andTOV21), kidney (Caki-2 and 769P), colon (HCT15 and LOV0), and liver (HepG2) carcinomas. B: $\beta$-Actin was used as a loading control. Correlation of ADAM28 protein expression and phosphorylation of c-Src ( $p-\mathrm{Src})$ in the human carcinoma cell lines. C: Down-regulation of ADAM28 expression by PP2 in PC-9, MDA-MB231, and RMUGL cells. Relative expression levels of ADAM28 and p-Src were quantitatively evaluated by densitometric analysis of the triplicate immunoblots. ${ }^{*} P<0.05$. IMB, immunoblotting; PCR, RT-PCR.

ErbB2-transformed MDCK cells, whereas no definite tumor was detected in the mouse tissues with implantation of Ha-Ras or c-Fos transformants or MDCK cells (Figure 3B). Similar tumor formation was observed when NOD/SCID mice received a s.c. injection of MDCK cells transformed with v-src, $L M P 1$, or ErbB2 (Supplemental Figure S1). Immunostaining was performed on the paraffin sections of tumors grown in the s.c. tissues of NOD/SCID mice, which showed less background signals compared with athymic nude mice. As shown in Figure 3C, both ADAM28 and phospho-Src were immunostained in v-src-transformed MDCK cells, but ADAM28 was negative with MDCK cells transformed with $L M P 1$ or ErbB2, which showed positive immunostaining for LMP1 or ErbB2.

\section{Intracellular Signaling Pathways Involved in v-src Transformants}

To investigate the signaling pathways for ADAM28 induction in v-src-transformed MDCK cells, we first examined the effects of Src inhibitors on ADAM28 expression. The expression levels of ADAM28 mRNA and protein were significantly, albeit slightly, down-regulated by treatment with Src inhibitor, PP2, compared with those in the samples treated with the structurally similar, but inactive, PP3 (Figure 4A). Although the inhibitor effect of PP2 to v-src transformants was partial, v-Src inhibitor, radicicol, downregulated ADAM28 expression and phosphorylation of Src (phospho-Src) to a negligible level (Figure 4A). To further determine the $\mathrm{v}$-Src downstream pathways, the effects of several pharmacological inhibitors to the molecules of the MAPK family were examined. As shown in Figure 4B, MEK inhibitors (PD98059 and U0126) suppressed the expression of ADAM28 and phospho-ERK1/2, whereas negative control U0124 showed no definite changes in expression. Inhibitors to other MAP kinases, JNK and p38, had no or negligible effects on the expression of ADAM28 or phosphoERK1/2 (Figure 4B and Supplemental Figure S2), indicating that these MAPK pathways are not involved in the ADAM28 
expression in v-src-transformed MDCK cells. In addition, negligible inhibition was observed by treatment with Ras inhibitors (FTI-277 and FPT inhibitor 1) (Supplemental Figure S3). PI3K inhibitor (LY294002) inhibited ADAM28 and phospho-Akt (Figure 4C) expression. mTOR inhibitor (rapamycin) reduced ADAM28 expression, with negligible inhibition of phospho-Akt (Figure 4C). Because the inhibition of ADAM28 expression was partial with either PD98059 or LY294002, we examined the additional effect of these inhibitors and found that simultaneous treatment with the inhibitors almost completely inhibits the expression of ADAM28 via suppression of phosphorylation of Akt and ERK1/2 (Figure 4D).

Involvement of Src Activation and Its Signaling Pathways in ADAM28 Expression in Human Carcinoma Cell Lines

Different from the canine cell line MDCK cells, human carcinoma cells express prototype ADAM28m and a spliced variant, ADAM28s. ${ }^{7,10,26}$ Thus, we first examined the expression of both ADAM28s and ADAM28m in human carcinoma cell lines established from carcinomas of the lung (PC-9 and Calu-3), breast (MDA-MB231 and MCF-7), ovary (RMUGL and TOV21G), kidney (Caki-2 and 769P), colon (HCT15 and LOVO), and liver (HepG2). As shown in Figure 5A, PC-9, Calu-3, MDA-MB231, RMUGL, Caki-2, and HCT15 cells expressed both forms of ADAM28, although the expression levels were different among the cell lines. All these cell lines expressed c-Src, and ADAM28s expression in the cell lines appeared to closely correlate with phosphorylation of Src (Figure 5B). In addition, ADAM28s expression in these cell lines was substantially down-regulated by treatment with Src kinase inhibitor, PP2, but not with inactive PP3 (Figure 5C and data not shown for Caki2, Calu-3, and HCT15 cells). All these data suggest that activation of $\mathrm{Src}$ is implicated in ADAM28 expression in human carcinoma cell lines.

To further study the Src signaling pathways involved in ADAM28 expression, PC-9 cells, which showed the highest expression of ADAM28 among the cell lines examined, were treated with various inhibitors. Down-regulation of ADAM28 expression with PP2 was associated with reduced expression of phospho-Src (Figure 6). In addition, phosphorylation of ERK1/2 and Akt, both of which are the Src downstream molecules, ${ }^{27,28}$ was also suppressed under this condition (Figure 6). Because these data suggest that both MEK/ERK and PI3K/Akt pathways are involved in the Srcmediated expression of ADAM28, the effects of the inhibitors specific to MEK (PD98059) and PI3K (LY294002) on ADAM28 expression were examined. We found that PD98059 reduces both ADAM28 expression and phosphorylation of ERK1/2 compared with their controls (Figure 6), and that LY294002 decreases ADAM28 expression and Akt phosphorylation (Figure 6). More important, simultaneous treatment with PD98059 and LY294002 almost completely inhibited the expression of ADAM28 (Figure 6).

\section{Co-Expression of ADAM28 and Phospho-Src in Human} Carcinomas

Because our experiments using human carcinoma cell lines suggested the implication of Src activation in ADAM28 expression, we performed IHC of ADAM28 and phosphoSrc in human carcinomas of the lung, breast, and colon, in which activation of $\mathrm{Src}$ is known. ${ }^{29}$ As we have previously reported, ${ }^{11,12}$ the cases of non-small cell lung carcinoma

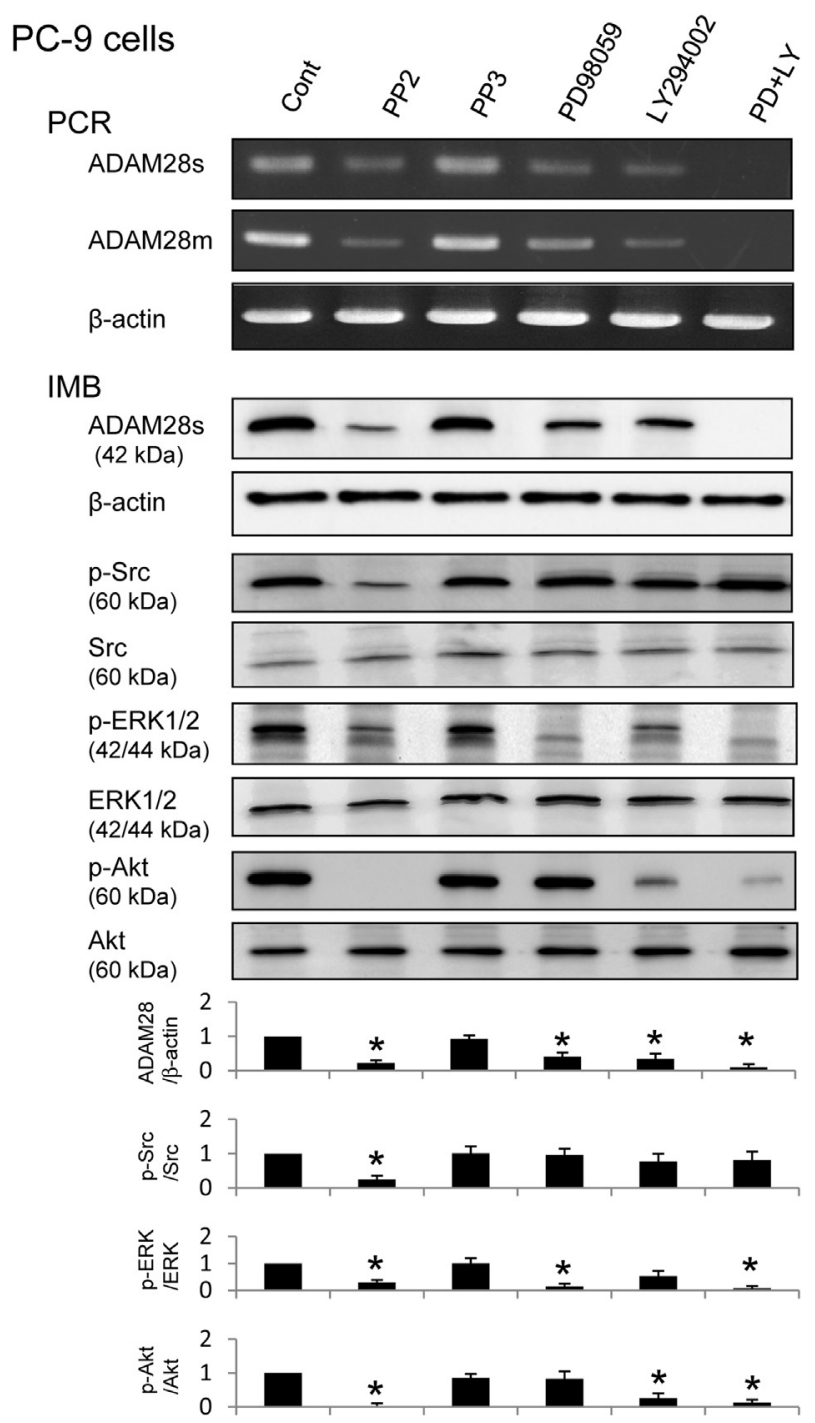

Figure 6 Involvement of Src activation and its downstream molecules ERK1/2 and Akt in ADAM28 expression in PC-9 cells. PC-9 cells were treated with PP2, MEK inhibitor (PD98059), PI3K inhibitor (LY294002), or combined MEK and PI3K inhibitors (PD + LY), and the expression of ADAM28, phospho-Src ( $p$-Src), phospho-ERK1/2 ( -ERK1/2), and phosphoAkt ( $p-A k t)$ was examined by RT-PCR (PCR) and immunoblotting (IMB). ADAM28 expression is partially inhibited by either MEK inhibitor or PI3K inhibitor, and almost completely by combined inhibitors. Relative expression levels of ADAM28 and signaling molecules were quantitatively evaluated by densitometric analysis of the triplicate immunoblots. ${ }^{\star} P<0.05$. 


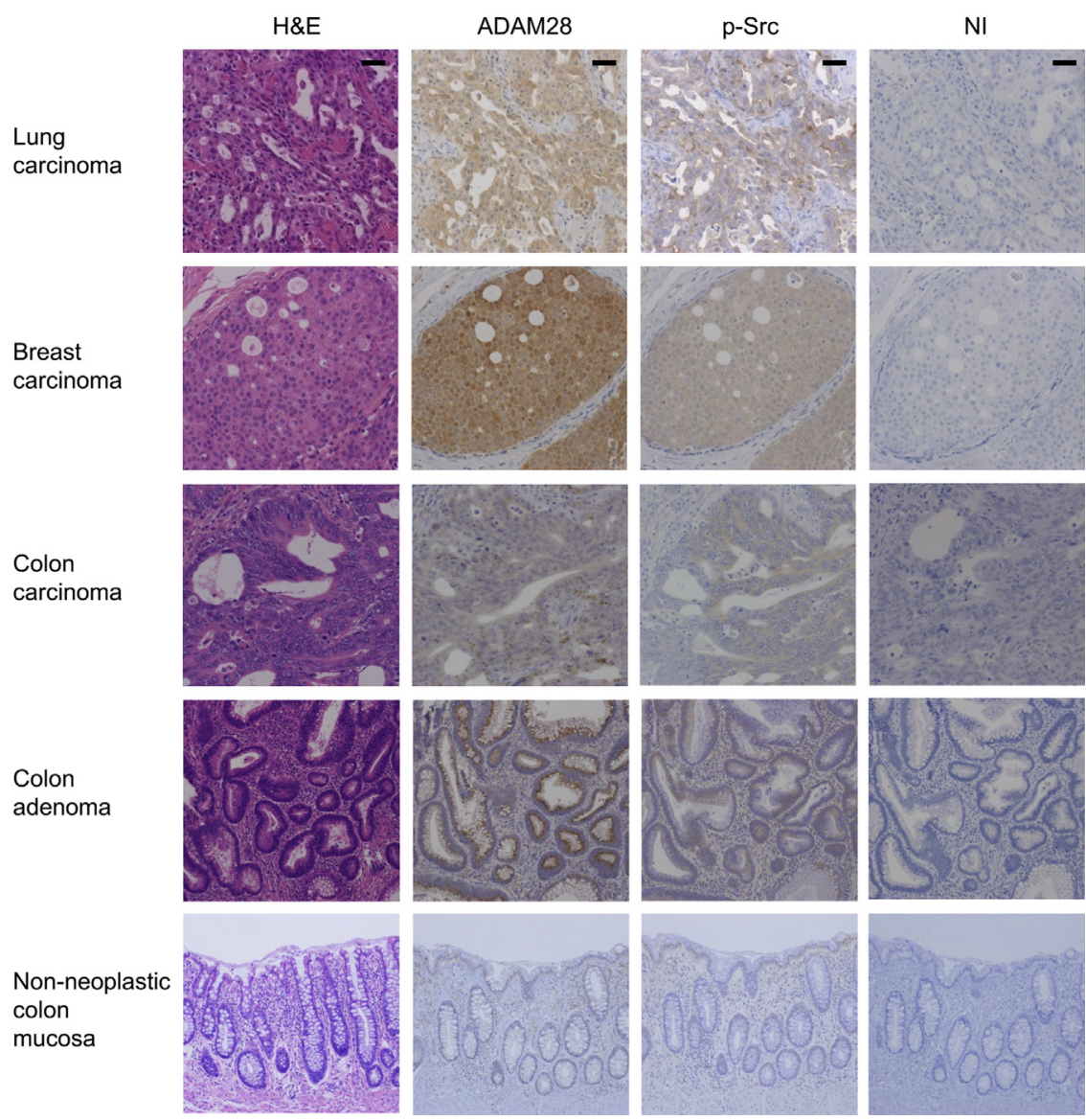

Figure 7 IHC of ADAM28 and phospho-Src ( $p$ $\mathrm{Src}$ ) in human carcinomas, colon adenomas, and nonneoplastic colon mucosa. Serial paraffin sections of carcinomas of the lung, breast, and colon, colon tubular adenomas, and nonneoplastic colon mucosa were immunostained for ADAM28 and $\mathrm{p}$-Src, according to the methods described in Materials and Methods. NI, nonimmune IgG. Scale bar $=50 \mu \mathrm{m}$. (six of six cases) and breast carcinoma (five of six cases) showed positive staining of ADAM28 in the carcinoma cells (Figure 7). More important, phospho-Src was coimmunostained in the ADAM28-positive cases (Figure 7). In colon adenocarcinoma cases, ADAM28 and phospho-Src were also co-expressed in 50\% of the cases (four of eight cases) (Figure 7). Tubular adenomas of the colon exhibited co-expression of ADAM28 and phospho-Src in $25 \%$ of the cases (two of eight cases), but nonneoplastic mucosa of the colon showed negligible staining of ADAM28 and phospho-Src (none of eight cases) (Figure 7). Negative controls for immunostaining using nonimmune IgG, instead of antibodies against ADAM28 or phospho-Src, showed only background staining (Figure 7).

\section{Discussion}

In the present study, to our knowledge, we have demonstrated, for the first time, that among the five different oncogene transformants, v-src-transformed MDCK cells selectively induce ADAM28 by activation of Src and its signaling pathways. Transformation of the cells by v-src induces dramatic cellular changes in morphological characteristics and behavior, which are related to malignant phenotypes. Although v-src-induced transformation affects many Src-downstream molecules, which include MMPs (eg, MT1-MMP and MMP-9), ${ }^{21,30}$ our xenograft experiments indicate that tumor growth in the s.c. tissue depends, at least in part, on the proteolytic activity of ADAM28 induced by v-src transformation, because anti-ADAM 28 antibody significantly suppressed the tumor growth.

The activities and functions of proteinase-type ADAM members are controlled by several steps, including gene expression, intracytoplasmic trafficking, activation on the cell membrane, and inhibition by tissue-derived inhibitors. ${ }^{7,9}$ Among them, regulation of the gene expression may be critical in cancer cells. Previous studies have shown that several factors induce and/or up-regulate the expression of $A D A M 8, A D A M 12, A D A M 15, A D A M 17, A D A M 19$, and $A D A M 28$. These include inflammatory cytokines and growth factors (ie, tumor necrosis factor- $\alpha$ for $A D A M 8$ in mouse primary astrocytes) ${ }^{31}$ IL-1 $\beta$ for $A D A M 17$ in neuroblastoma cells, ${ }^{32}$ vascular endothelial growth factor ${ }_{165}\left(\mathrm{VEGF}_{165}\right)$ for $A D A M 15$ in human umbilical vein endothelial cells, ${ }^{33}$ and transforming growth factor- $\beta$ for $A D A M 12$ in human breast carcinoma cells ${ }^{34}$ and for $A D A M 19$ in alveolar epithelial cells. ${ }^{35}$ On the other hand, ADAM28 is induced in human monocyte-like THP-1 cells by treatment with phorbol myristate acetate or low-density lipoprotein. ${ }^{19,20}$ These factors 
may play roles in induction and up-regulation of $A D A M$ gene expression in nonneoplastic and neoplastic cells. However, because our study has provided the evidence that oncogeneinduced transformation of epithelial cells causes the expression of ADAM9, ADAM10, ADAM12, and ADAM28, oncogene-modulated transformation seems to be another key regulation mechanism of $A D A M$ gene expression in cancer cells.

Src is closely related to the activity of ADAM members, including ADAM9, ADAM12, ADAM15, and ADAM17. The cytoplasmic domains of these ADAM species have the Tyr and Ser/Thr phosphorylation sites that are potential sites for phosphorylation by diverse kinases, and the common PXXP motifs, which are putative binding sites for Src homology 3 (SH3) domain-containing proteins, such as cSrc. ${ }^{2,5,9}$ Therefore, the ADAM species containing the motifs may directly bind to the $\mathrm{SH} 3$ domain of $\mathrm{Src}$ and modulate the kinase activity. ${ }^{2,5}$ Actually, ADAM9 and ADAM12 are known to bind to the SH3 domain of Src. ${ }^{36,37}$ ADAM12 can activate endogenous Src through the binding between the intracytoplasmic tail domain and the SH3 domain of Src, and the interaction promotes cell differentiation. ${ }^{37}$ Although these studies did not investigate changes in the proteolytic activity of the ADAM species after the interactions with Src, a recent study has demonstrated that ADAM15B, a splice variant of ADAM15 with an SH3-binding site, shows enhanced catalytic activity of fibroblast growth factor receptor- 2 shedding through the interaction between Src and SH3-binding site of ADAM15B, compared with ADAM15A without the binding site. ${ }^{38}$ These data suggest that the interactions of ADAM SH3-binding sites with Src can activate their proteolytic activity, probably through conformational changes of the molecules. On the other hand, Maretzky et $\mathrm{al}^{39}$ reported that mouse embryonic fibroblasts, transformed by v-src, enhance the shedding of epidermal growth factor receptor (EGFR) ligands by ADAM17 activity, and that growth factor-stimulated migration of keratinocytes and endothelial cells requires EGFR transactivation by Srcmediated ADAM17 activation, which is independent of the cytoplasmic domain of ADAM17. ${ }^{40}$ A recent study also showed that ATP-mediated EGFR transactivation by ADAM17 involves activation of Src and ADAM17 by cysteine oxidation, but not the direct interaction of the cytoplasmic domain of ADAM17 with the SH3 domain of Src. ${ }^{41}$ Because neither canine nor human ADAM28 has SH3binding sites within the molecules, ${ }^{5}$ our study also indicates the SH3-independent pathway on the ADAM28 induction via the transformation by $\mathrm{v}-s r c$.

The expression of $\mathrm{v}-\mathrm{src}$ causes activation of several signaling pathways. ${ }^{42} \mathrm{We}$, therefore, examined the involvement of the MEK/ERK, PI3K/Akt/mTOR, p38 MAPK, and JNK pathways in ADAM28 expression by treating v-srctransformed MDCK cells with their specific inhibitors. Inhibition of either the MEK/ERK or PI3K/Akt/mTOR pathway partially reduced ADAM28 expression, and simultaneous inhibition of both pathways almost completely blocked the expression; however, there were no or negligible effects of p38 and JNK MAPK inhibitors on ADAM28 expression. Therefore, we propose the hypothesis that both MEK/ERK and PI3K/Akt/mTOR pathways contribute to the expression of ADAM28 (Figure 8). The canonical MEK/ ERK pathway is initiated by activation of Raf protein kinase with Ras. ${ }^{42,43}$ In the present study, ADAM28 expression was not detected in Ha-Ras-transformed MDCK cells, although our study did not completely exclude the possibility that stronger activation of Ha-Ras in the transformants could induce ADAM28. In addition, ADAM28 expression in v-src transformants was not inhibited by Ras inhibitors. These data suggest that Ras plays a minimal role, if any, in ADAM28 expression. Prolactin-stimulated activation of the MEK/ERK cascade is reportedly induced through the PI3K-dependent Rac/PAK/Raf/MEK pathway in breast carcinoma cell lines, ${ }^{43}$ but this pathway may not be applicable to ADAM28 expression in v-src transformants, because PI3K inhibitor did not completely block the expression. On the other hand, Src is known to directly activate Raf protein kinase through interaction with CNK1 scaffold protein. ${ }^{44}$ Altogether, it seems likely that the MEK/ERK and the PI3K/Akt/mTOR pathways in the $\mathrm{v}-s r c$ transformants are independently activated by v-Src for ADAM28 expression (Figure 8).

Src kinase is overexpressed and/or frequently activated by tumor cells in $50 \%$ to $100 \%$ of cases of various malignant neoplasms, including breast, ${ }^{45}$ lung, ${ }^{46}$ ovarian, ${ }^{47}$ colon, ${ }^{48-50}$ stomach, ${ }^{51}$ pancreas, ${ }^{52}$ and prostate carcinomas. ${ }^{53}$ Our IHC findings showing common expression of phospho-Src in the lung, breast, and colon carcinomas confirm the previous data, and further demonstrate that the phospho-Src staining is

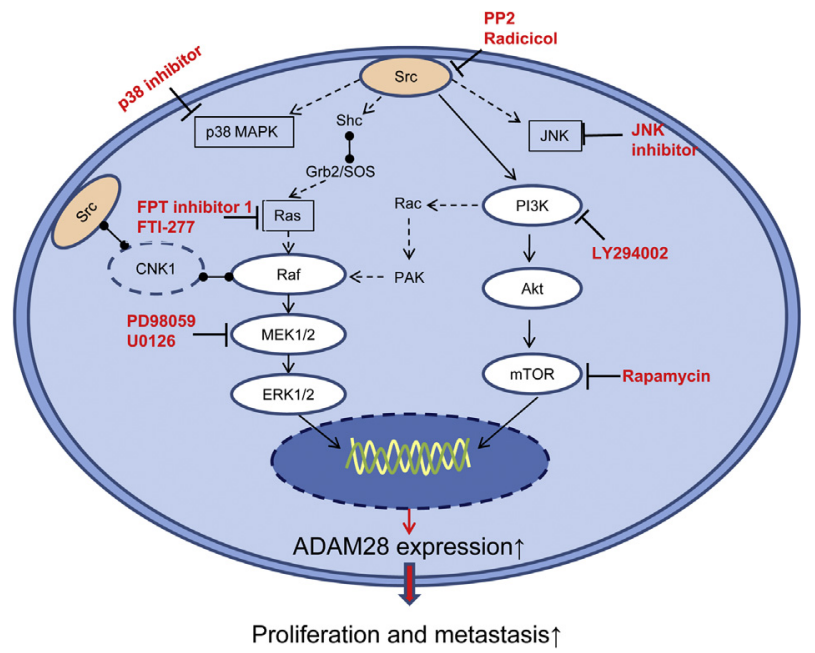

Figure 8 Schematic presentation of the Src effector pathways that may be involved in Src-induced expression of ADAM28. Solid lines with arrows indicate the activation or phosphorylation of proteins suggested for the Src-induced ADAM28 expression. Dotted lines with arrows show the activation or phosphorylation of proteins, which has been demonstrated by other studies but not in the present study. Solid lines with circular ends represent protein-protein interactions. Pharmacological inhibitors to $\mathrm{Src}$ (PP2 and radicicol), MEK (PD98059 and U0126), JNK, p38 MAPK, PI3K (LY294002), mTOR (rapamycin), and Ras (FTI-277 and FPT inhibitor 1) used in the present study are shown in red. 
colocalized with ADAM28 expression in these carcinomas. Elevated activation of Src kinase has been detected in colon adenomas with severe dysplasia ${ }^{54}$ and even in mildly dysplastic epithelial cells associated with ulcerative colitis. ${ }^{55}$ In the current study, we observed colocalization of phosphoSrc and ADAM 28 in 25\% of cases of tubular adenomas, whereas we observed only negligible expression in nonneoplastic colonic epithelia. All these data on the co-expression of ADAM28 and phospho-Src in human carcinomas and premalignant lesions support our notion that Src is a key inducer for $A D A M 28$ gene expression in neoplastic epithelial cells.

Src is implicated in pathways regulating cellular proliferation, survival, disruption of cell-to-cell interactions, migration, invasion, metastasis, and angiogenesis. ${ }^{27-29,56}$ These pleotropic effects of $\mathrm{Src}$ on cellular function are considered to involve many downstream pathways and mechanisms. However, ADAM28 promotes carcinoma cell proliferation, through enhanced bioavailability of IGF-I by digesting IGFBP-3, ${ }^{12,14}$ and angiogenesis, via release of VEGF $_{165}$ from the VEGF $_{165} /$ CTGF complex by CTGF digestion. ${ }^{16}$ In addition, our recent study has demonstrated that ADAM28 promotes cell survival within blood vessels by escaping from VWF-induced apoptosis of carcinoma cells by degrading VWF, leading to increased lung metastasis. ${ }^{15}$ Thus, all these data suggest that malignant phenotypes of carcinoma cells with Src activation may be due, at least in part, to the proteolytic digestion of substrates by ADAM28 expressed via activation of Src kinase. Src is one of the molecular targets for human malignant neoplasms, and several drugs targeting Src kinase are under clinical trials. ${ }^{27,28,56}$ Therefore, pharmacological inhibition of Src activity may have dual influences (ie, direct effects by inhibition of Src activity and secondary effects on ADAM28 expression), and might be a promising remedy for carcinomas with Src activation and ADAM28 expression.

\section{Acknowledgments}

We thank Aya Shiraishi and Yukie Mizutani for their technical assistance.

\section{Supplemental Data}

Supplemental material for this article can be found at http://dx.doi.org/10.1016/j.ajpath.2013.07.011.

\section{References}

1. Edwards DR, Handsley MM, Pennington CJ: The ADAM metalloproteinases. Mol Aspects Med 2008, 29:258-289

2. Murphy G: Regulation of the proteolytic disintegrin metalloproteinases, the "Sheddases." Semin Cell Dev Biol 2009, 20: 138-145

3. Shiomi T, Lemaitre V, D'Armiento J, Okada Y: Matrix metalloproteinases, a disintegrin and metalloproteinases, and a disintegrin and metalloproteinases with thrombospondin motifs in non-neoplastic diseases. Pathol Int 2010, 60:477-496

4. White JM: ADAMs: modulators of cell-cell and cell-matrix interactions. Curr Opin Cell Biol 2003, 15:598-606

5. Seals DF, Courtneidge SA: The ADAMs family of metalloproteases: multidomain proteins with multiple functions. Genes Dev 2003, 17: 7-30

6. Blobel CP: ADAMs: key components in EGFR signalling and development. Nat Rev Mol Cell Biol 2005, 6:32-43

7. Mochizuki S, Okada Y: ADAMs in cancer cell proliferation and progression. Cancer Sci 2007, 98:621-628

8. Okada Y: Proteinases and Matrix Degradation. Edited by Firestein GS, Budd RC, Harris ED Jr, McInnes IB, Ruddy S, Sergent JS. ed 8. Philadelphia, Elsevier Saunders, 2009, pp 115-134

9. Murphy G: The ADAMs: signalling scissors in the tumour microenvironment. Nat Rev Cancer 2008, 8:929-941

10. Mochizuki S, Okada Y: ADAM28 as a target for human cancers. Curr Pharm Des 2009, 15:2349-2358

11. Ohtsuka T, Shiomi T, Shimoda M, Kodama T, Amour A, Murphy G, Ohuchi E, Kobayashi K, Okada Y: ADAM28 is overexpressed in human non-small cell lung carcinomas and correlates with cell proliferation and lymph node metastasis. Int J Cancer 2006, 118: $263-273$

12. Mitsui Y, Mochizuki S, Kodama T, Shimoda M, Ohtsuka T, Shiomi T, Chijiiwa M, Ikeda T, Kitajima M, Okada Y: ADAM28 is overexpressed in human breast carcinomas: implications for carcinoma cell proliferation through cleavage of insulin-like growth factor binding protein-3. Cancer Res 2006, 66:9913-9920

13. Kuroda H, Mochizuki S, Shimoda M, Chijiiwa M, Kamiya K, Izumi Y, Watanabe M, Horinouchi H, Kawamura M, Kobayashi K, Okada Y: ADAM28 is a serological and histochemical marker for non-small-cell lung cancers. Int J Cancer 2010, 127:1844-1856

14. Mochizuki S, Shimoda M, Shiomi T, Fujii Y, Okada Y: ADAM28 is activated by MMP-7 (matrilysin-1) and cleaves insulin-like growth factor binding protein-3. Biochem Biophys Res Commun 2004, 315 : 79-84

15. Mochizuki S, Soejima K, Shimoda M, Abe H, Sasaki A, Okano HJ, Okano H, Okada Y: Effect of ADAM28 on carcinoma cell metastasis by cleavage of von Willebrand factor. J Natl Cancer Inst 2012, 104 : 906-922

16. Mochizuki S, Tanaka R, Shimoda M, Onuma J, Fujii Y, Jinno H, Okada Y: Connective tissue growth factor is a substrate of ADAM28. Biochem Biophys Res Commun 2010, 402:651-657

17. Wright CM, Larsen JE, Hayward NK, Martins MU, Tan ME, Davidson MR, Savarimuthu SM, McLachlan RE, Passmore LH, Windsor MN, Clarke BE, Duhig EE, Yang IA, Bowman RV, Fong KM: ADAM28: a potential oncogene involved in asbestosrelated lung adenocarcinomas. Genes Chromosomes Cancer 2010, 49:688-698

18. Yang MH, Chu PY, Chen SC, Chung TW, Chen WC, Tan LB, Kan WC, Wang HY, Su SB, Tyan YC: Characterization of ADAM28 as a biomarker of bladder transitional cell carcinomas by urinary proteome analysis. Biochem Biophys Res Commun 2011, 411: $714-720$

19. Worley JR, Baugh MD, Hughes DA, Edwards DR, Hogan A, Sampson MJ, Gavrilovic J: Metalloproteinase expression in PMAstimulated THP-1 cells: effects of peroxisome proliferator-activated receptor-gamma (PPAR gamma) agonists and 9-cis-retinoic acid. J Biol Chem 2003, 278:51340-51346

20. Worley JR, Hughes DA, Dozio N, Gavrilovic J, Sampson MJ: Low density lipoprotein from patients with type 2 diabetes increases expression of monocyte matrix metalloproteinase and ADAM metalloproteinase genes. Cardiovasc Diabetol 2007, 6:21

21. Kadono Y, Okada Y, Namiki M, Seiki M, Sato H: Transformation of epithelial Madin-Darby canine kidney cells with p60(v-src) induces expression of membrane-type 1 matrix metalloproteinase and invasiveness. Cancer Res 1998, 58:2240-2244 
22. Miyamori H, Hasegawa K, Kim KR, Sato H: Expression of metastasis-associated $\mathrm{mts} 1$ gene is co-induced with membrane type-1 matrix metalloproteinase (MT1-MMP) during oncogenic transformation and tubular formation of Madin Darby canine kidney (MDCK) epithelial cells. Clin Exp Metastasis 2000, 18:51-56

23. Kim KR, Yoshizaki T, Miyamori H, Hasegawa K, Horikawa T, Furukawa M, Harada S, Seiki M, Sato H: Transformation of MadinDarby canine kidney (MDCK) epithelial cells by Epstein-Barr virus latent membrane protein 1 (LMP1) induces expression of Ets1 and invasive growth. Oncogene 2000, 19:1764-1771

24. Reddy EP, Reynolds RK, Santos E, Barbacid M: A point mutation is responsible for the acquisition of transforming properties by the T24 human bladder carcinoma oncogene. Nature 1982, 300: $149-152$

25. Miller AD, Curran T, Verma IM: c-Fos protein can induce cellular transformation: a novel mechanism of activation of a cellular oncogene. Cell 1984, 36:51-60

26. Roberts CM, Tani PH, Bridges LC, Laszik Z, Bowditch RD: MDC-L, a novel metalloprotease disintegrin cysteine-rich protein family member expressed by human lymphocytes. J Biol Chem 1999, 274: 29251-29259

27. Wheeler DL, Iida M, Dunn EF: The role of Src in solid tumors. Oncologist 2009, 14:667-678

28. Mayer EL, Krop IE: Advances in targeting SRC in the treatment of breast cancer and other solid malignancies. Clin Cancer Res 2010, 16: 3526-3531

29. Summy JM, Gallick GE: Src family kinases in tumor progression and metastasis. Cancer Metastasis Rev 2003, 22:337-358

30. Sato H, Kita M, Seiki M: v-Src activates the expression of $92-\mathrm{kDa}$ type IV collagenase gene through the AP-1 site and the GT box homologous to retinoblastoma control elements: a mechanism regulating gene expression independent of that by inflammatory cytokines. J Biol Chem 1993, 268:23460-23468

31. Schlomann U, Rathke-Hartlieb S, Yamamoto S, Jockusch H, Bartsch JW: Tumor necrosis factor alpha induces a metalloproteasedisintegrin, ADAM8 (CD 156): implications for neuron-glia interactions during neurodegeneration. J Neurosci 2000, 20:7964-7971

32. Tachida $\mathrm{Y}$, Nakagawa K, Saito T, Saido TC, Honda T, Saito Y, Murayama S, Endo T, Sakaguchi G, Kato A, Kitazume S, Hashimoto Y: Interleukin-1 beta up-regulates TACE to enhance alpha-cleavage of APP in neurons: resulting decrease in Abeta production. J Neurochem 2008, 104:1387-1393

33. Komiya K, Enomoto H, Inoki I, Okazaki S, Fujita Y, Ikeda E, Ohuchi E, Matsumoto H, Toyama Y, Okada Y: Expression of ADAM15 in rheumatoid synovium: up-regulation by vascular endothelial growth factor and possible implications for angiogenesis. Arthritis Res Ther 2005, 7:R1158-R1173

34. Ray A, Dhar S, Ray BK: Transforming growth factor-beta1-mediated activation of NF-kappaB contributes to enhanced ADAM-12 expression in mammary carcinoma cells. Mol Cancer Res 2010, 8: $1261-1270$

35. Keating DT, Sadlier DM, Patricelli A, Smith SM, Walls D, Egan JJ, Doran PP: Microarray identifies ADAM family members as key responders to TGF-beta1 in alveolar epithelial cells. Respir Res 2006, 7:114

36. Weskamp G, Kratzschmar J, Reid MS, Blobel CP: MDC9, a widely expressed cellular disintegrin containing cytoplasmic SH3 ligand domains. J Cell Biol 1996, 132:717-726

37. Kang Q, Cao Y, Zolkiewska A: Metalloprotease-disintegrin ADAM 12 binds to the SH3 domain of Src and activates Src tyrosine kinase in C2C12 cells. Biochem J 2000, 352(Pt 3):883-892

38. Maretzky T, Le Gall SM, Worpenberg-Pietruk S, Eder J, Overall CM, Huang XY, Poghosyan Z, Edwards DR, Blobel CP: Src stimulates fibroblast growth factor receptor-2 shedding by an ADAM15 splice variant linked to breast cancer. Cancer Res 2009, 69:4573-4576

39. Maretzky T, Zhou W, Huang XY, Blobel CP: A transforming Src mutant increases the bioavailability of EGFR ligands via stimulation of the cell-surface metalloproteinase ADAM17. Oncogene 2011, 30: 611-618

40. Maretzky T, Evers A, Zhou W, Swendeman SL, Wong PM, Rafii S, Reiss K, Blobel CP: Migration of growth factor-stimulated epithelial and endothelial cells depends on EGFR transactivation by ADAM17. Nat Commun 2011, 2:229

41. Sham D, Wesley UV, Hristova M, van der Vliet A: ATP-mediated transactivation of the epidermal growth factor receptor in airway epithelial cells involves DUOX1-dependent oxidation of Src and ADAM17. PLoS One 2013, 8:e54391

42. Finn RS: Targeting Src in breast cancer. Ann Oncol 2008, 19: 1379-1386

43. Aksamitiene E, Achanta S, Kolch W, Kholodenko BN, Hoek JB, Kiyatkin A: Prolactin-stimulated activation of ERK1/2 mitogenactivated protein kinases is controlled by $\mathrm{PI} 3$-kinase/Rac/PAK signaling pathway in breast cancer cells. Cell Signal 2011, 23: $1794-1805$

44. Ziogas A, Moelling K, Radziwill G: CNK1 is a scaffold protein that regulates Src-mediated Raf-1 activation. J Biol Chem 2005, 280: 24205-24211

45. Ottenhoff-Kalff AE, Rijksen G, van Beurden EA, Hennipman A, Michels AA, Staal GE: Characterization of protein tyrosine kinases from human breast cancer: involvement of the c-src oncogene product. Cancer Res 1992, 52:4773-4778

46. Mazurenko NN, Kogan EA, Zborovskaya IB, Kisseljov FL: Expression of pp60c-src in human small cell and non-small cell lung carcinomas. Eur J Cancer 1992, 28:372-377

47. Wiener JR, Windham TC, Estrella VC, Parikh NU, Thall PF, Deavers MT, Bast RC, Mills GB, Gallick GE: Activated SRC protein tyrosine kinase is overexpressed in late-stage human ovarian cancers. Gynecol Oncol 2003, 88:73-79

48. Cartwright CA, Kamps MP, Meisler AI, Pipas JM, Eckhart W: pp60c-Src activation in human colon carcinoma. J Clin Invest 1989, 83:2025-2033

49. Talamonti MS, Roh MS, Curley SA, Gallick GE: Increase in activity and level of pp60c-src in progressive stages of human colorectal cancer. J Clin Invest 1993, 91:53-60

50. Han NM, Curley SA, Gallick GE: Differential activation of pp60 (c-src) and pp62(c-yes) in human colorectal carcinoma liver metastases. Clin Cancer Res 1996, 2:1397-1404

51. Takekura N, Yasui W, Yoshida K, Tsujino T, Nakayama H, Kameda T, Yokozaki H, Nishimura Y, Ito H, Tahara E: pp60c-Src protein kinase activity in human gastric carcinomas. Int J Cancer 1990, 45:847-851

52. Lutz MP, Esser IB, Flossmann-Kast BB, Vogelmann R, Luhrs H, Friess H, Buchler MW, Adler G: Overexpression and activation of the tyrosine kinase $\mathrm{Src}$ in human pancreatic carcinoma. Biochem Biophys Res Commun 1998, 243:503-508

53. Tatarov O, Mitchell TJ, Seywright M, Leung HY, Brunton VG, Edwards J: SRC family kinase activity is up-regulated in hormonerefractory prostate cancer. Clin Cancer Res 2009, 15:3540-3549

54. Cartwright CA, Meisler AI, Eckhart W: Activation of the pp60c-src protein kinase is an early event in colonic carcinogenesis. Proc Natl Acad Sci U S A 1990, 87:558-562

55. Cartwright CA, Coad CA, Egbert BM: Elevated c-Src tyrosine kinase activity in premalignant epithelia of ulcerative colitis. J Clin Invest 1994, 93:509-515

56. Aleshin A, Finn RS: SRC: a century of science brought to the clinic. Neoplasia 2010, 12:599-607 